\title{
Writing Competency of Inspirational Stories Through ATAP Method in Asosiasi Guru Belajar
}

\author{
Nani Solihati ${ }^{1}$, Imam Safii ${ }^{2}$, Rugi Astutik $^{3}$ \\ ${ }^{1,2,3)}$ Universitas Muhammadiyah Prof. Dr. HAMKA \\ Jl. Warung Jati Barat, Blok Darul Muslimin No.17 RT.2/RW, RT.2/RW.5, Kalibata, Kec. Pancoran, Kota Jakarta Selatan, Daerah \\ Khusus Ibukota Jakarta 12740, 0812-8500-9697 \\ r.astutik001@gmail.com
}

\begin{abstract}
Writing Competency of inspirational stories through ATAP Method in Asosiasi Guru Belajar. This Paper aims to describe the writing competencies of teachers in Asosiasi Guru Belajar in delineate the awalan, tantangan, aksi, dan pelajaran of the teachers' inspirational stories. Method was used in the research is a descriptive qualitative method. Data were obtained scientifically by collecting techniques from the case studies including an occurrence, actual condition of situation /circumstance, and the environment or certain condition of people or everything. The research was carried out on 31 writing projects of Asosiasi Guru Belajar teachers. This research can be concluded that the writing competency of the teachers in describing the beginning part of the stories is categorised in low criteria. It is proven by the percentage of the data reaching $48,39 \%$. However, the writing competencies of the teachers in describing the challenge, action and lesson parts are categorised in high criteria. Those are shown by the percentage of the data attaining $83.87 \%, 100 \%$ and $93,55 \%$ consecutively. The authors hope that beginning, challenge, action and lesson or ATAP (Awalan, Tantangan, Aksi dan Pelajaran) can be an innovative theory about inspirational story writing methods. Furthermore, the teachers can apply the ATAP method in the classroom for writing skills, thus the students are able to enhance their writing competencies because the theories are applied easily.
\end{abstract}

Keywords: writing competency, inspirational stories, ATAP method.

\section{INTRODUCTION}

Every human being has problems in life. Humans need enthusiasm from others, either directly or indirectly. One way to encourage others is to write an inspirational story. Inspirational stories are stories that motivate readers or listeners to do something better. The inspirational story according to [1] is a type of narrative text that presents an inspiring example for many people. This text inspires someone to do good as a result of inspiration from the stories in it. Stories like this are often referred to as exemplary stories or stories full of wisdom. So, inspirational stories can inspire readers or listeners to find solutions to the conflict at hand. For writers, writing inspirational stories can be therapeutic to relax the mind and calm the heart.In the world of education the role of the teacher is very important, according to Dharma's competence [2] is the ability to carry out or perform a job or task which is based on skills and knowledge and is supported by the work attitude required by the job. According to Echols and Shadly (in Emilda, 2015: 6), competence is a collection of knowledge, behavior, and skills that teachers must possess to achieve learning and educational goals. 
Competence is obtained through education, training, and independent learning by utilizing learning resources. The competencies that teachers must have to face the industrial revolution 4.0 are in the field of literacy.

The 2018 Program for International Student Assessment (PISA) report released by the Organization for Economic Co-operation and Development (OECD) shows that the quality of education in Indonesia is low [3]. All indicators of Indonesia's PISA have decreased in recent years. The results of the 2018 PISA study released by the OECD showed that the ability of Indonesian students to read, achieved an average score of 371 , with an average OECD score of 487. This figure is the lowest since 2000. As a result, Indonesia's reading ranking has dropped from 64 countries to 74 countries. The 2018 PISA survey involved 600 thousand children aged 15 from 79 countries.

Based on the results of the PISA survey above, it is important to conduct research on teacher competence. Teacher competence in teaching is an important factor in student success in literacy. Literacy must be mastered by students for the development of a country. Literacy is an important factor in critical and innovative thinking so that students are able to compete globally.

Teacher competence is a set of knowledge, skills, and behaviors that a teacher must possess, live and master in carrying out his professional duties. In PP No. 19 of 2005 article 28 paragraph 3 states that competence as a learning agent at the primary and secondary education and early childhood education includes pedagogic, personal, professional, and social competence [4]. Teachers have an important role in educating the nation's buds. If the teacher has the competence and applies it in learning, Indonesian education will increase. The main competency for improving Indonesian education is literacy in reading and writing.

This research was conducted to collect comprehensive data on the competence of teachers who are involved in the Teacher Learning Association in compiling inspirational stories using the ATAP method. Through the competence of developing inspirational stories, it is hoped that teachers can reflect on life and improve themselves to become professional teachers. Teachers can share experiences and knowledge in theory and practice with students. Competent teachers will produce superior students. This research method uses the method of ATAP (Prefix, Challenge, Action, and Lessons). The advantages of the method are 1) the structure is simple and easy to understand, 2) helps the flow of thought to develop an inspirational story, and 3) is easy to apply.
Research carried out by researchers originates from previous research that has been conducted by other studies. Researchers refer to research related to writing inspirational stories. There are three studies that are still relevant to this research. Researchers found three research topics regarding reading inspirational stories entitled " Pemanafaatan Video Kisah Inspiratif sebagai Inovasi Pembelajan PPKn guna Meningkatkan Kesadaran Bela Negara pada Siswa" by [5] The results of the research that have been done, it can be seen that students become motivated and unconsciously students are required to become individuals who have high enthusiasm for learning and have awareness of defending the country and instilling a fighting spirit to achieve goals for the country and nation.

The second research is "Peningkatan Keterampilan Menulis Teks Cerita Inspiratif melalui Model Discovery Learning Siswa Kelas IX SMP Negeri 1 Kota Sawahlunto. In Seminar Nasional Teknologi Pembelajaran dan Pendidikan Dasar 2017 " by [6] The use of the Discovery Learning model supports students to think logically, critically, and systematically in writing inspirational story texts and [7] Pengaruh Menonton Film Terhadap Kemampuan Menulis Cerita Inspiratif oleh SiswaKelas IX SMP Negeri 40 Medan

The urgency of the research is synthesized from the results of the analysis of the reality of the low writing ability of the object under study and the results of previous studies that have not explored in depth the use of the ATAP method (prefixes, challenges, actions, and lessons) in supporting inspirational story writing activities. Based on this explanation, the purpose of this study is to describe the Competence of Writing Inspirational Stories through the ATAP Method at the Learning Teacher Association.

\section{RESEARCH METHOD}

This research is concerned with the competence of writing inspirational stories through the ATAP method. This study is based on content analysis techniques. The stages in this study consisted of three stages, namely (1) reading orientation: the researcher explored data about the competence of teachers in writing inspirational stories using the ATAP method. (2) exploration: the researcher clarifies or coding the data based on the prefixes, challenges, actions, and lessons. The prefix part is the teacher's competence in describing the author's goals / expectations. Part of the challenge, namely the competence of teachers in describing problems that arise is inversely proportional to the expectations of the author. The action part is the 
teacher's competence in describing ideas or solutions in solving challenges. Part of the lesson is the competence of the teacher in describing the reflection of the action or value obtained. (3) Member Check: the researcher checks the data based on the instrument grid. The data collection instrument used was a criteria sheet containing a number of indicators about prefixes, challenges, actions, and lessons. Teacher competency data in writing inspirational stories is measured by looking at the stages of the process, namely the prefix includes objectives, character recognition, characterizations, and settings. The challenge section covers the challenge, the origin of the obstacles, and the path of the problem. The action section includes the strategy, the steps, and the fun part of the action. The lesson section includes lessons, grades, and inspiration. Then the value-based evaluation instrument from the inspirational story, namely education, character, religion, culture, and economy. The data sources in this study were 31 inspirational story texts written by the teacher.

\section{RESEARCH RESULT}

The results of this data analysis consisted of the teacher's competence in describing part A (prefix), describing part $\mathrm{T}$ (challenge), describing part A (action), and describing part $\mathrm{P}$ (lesson). For more details, it can be seen in details of the results of the analysis of teacher competency data in writing inspirational stories using the ATAP method as follows:

\subsection{Description of Part A}

Part A is the part that tells the initial situation. This section tells the author's goals. The author's goals can be seen through indicators such as (1) describing the purpose / life expectancy, (2) introducing the characters and characterizations, and (3) telling the setting of time, place, and circumstances / atmosphere. More details can be seen in the description table A below.

Table 1. Teacher Competence in Describing A

\begin{tabular}{|l|c|c|c|}
\hline \multicolumn{3}{|c|}{ Score } \\
\hline Indicator & $\begin{array}{l}\text { Description of purpose / } \\
\text { life expectancy }\end{array}$ & $\begin{array}{l}\text { Introducing characters and } \\
\text { characterizations }\end{array}$ & $\begin{array}{l}\text { Tells the setting of time, place, and } \\
\text { circumstances / atmosphere }\end{array}$ \\
\hline average (\%) & $68,55 \%$ & $84,68 \%$ & $85,68 \%$ \\
\hline
\end{tabular}

\subsection{Description of Part T}

Part $\mathrm{T}$ is the part that tells the challenge or difficulty received to achieve the goal in the beginning. These challenges are inversely proportional to expectations. The writer's challenge can be seen through indicators such as (1) describing the challenge, (2) describing the origin of the obstacle (character characteristics, community attitudes, geographical conditions), and (3) telling the flow of the problem coherently (introduction to conflict, conflict, climax, and anti-climax). More details can be seen in the $\mathrm{T}$ description table below.

Table 2. Teacher Competence in Describing Part $\mathbf{T}$

\begin{tabular}{|l|c|c|c|}
\hline \multicolumn{5}{|c|}{ Score } \\
\hline Indikator & Describe the challenge & $\begin{array}{l}\text { Describe the origin of the } \\
\text { obstacle }\end{array}$ & $\begin{array}{l}\text { Tell the flow of the problem } \\
\text { coherently }\end{array}$ \\
\hline Average $(\%)$ & $90,30 \%$ & \multicolumn{1}{|c|}{$95,16 \%$} & $86,29 \%$ \\
\hline
\end{tabular}

\subsection{Description of Part A}

Part A (Aksi) is a section that tells the strategy and implementation of strategies to solve challenges. These actions are taken to face or complete challenges. The writer's action can be seen through indicators such as (1) describing the character's preparation strategy, describing the steps taken by the character, and (3) describing the exciting part or response of another character. More details can be seen in the description table A below. 
Table 3. Teacher Competence in Describing Part A (Aksi)

\begin{tabular}{|l|l|l|l|}
\hline \multicolumn{3}{|c|}{ Score } \\
\hline Indicator & $\begin{array}{l}\text { Describes the character's } \\
\text { preparation strategy }\end{array}$ & $\begin{array}{l}\text { Describes the steps taken } \\
\text { by the character }\end{array}$ & $\begin{array}{l}\text { Describes the fun part or } \\
\text { response of another character }\end{array}$ \\
\hline Average (\%) & $100 \%$ & $100 \%$ & $100 \%$ \\
\hline
\end{tabular}

\subsection{Description of Part $P$}

Part $\mathrm{P}$ is the part that tells the lesson of reflection on the whole story. This section contains moral messages that are very meaningful and can inspire readers. The author's lessons can be seen through indicators such as (1) describing the lessons that have been obtained from both implied and implicit actions, (2) describing values, and (3) inspiring readers. More details can be seen in the $\mathrm{P}$ description table below.

Table 4. Teacher Competence in Describing Part $P$

\begin{tabular}{|l|c|c|c|}
\hline \multicolumn{3}{|c|}{ Score } \\
\hline Indicator & $\begin{array}{l}\text { Describes lessons learned from } \\
\text { the action, implied or implicit }\end{array}$ & Describes value & Inspires readers \\
\hline Average (\%) & $95,16 \%$ & $95,16 \%$ & $95,16 \%$ \\
\hline
\end{tabular}

\section{DISCUSSION}

The results of previous research are related to the scientific fields that the researchers studied. Based on the data analysis above, the average teacher competency in writing inspirational stories using the ATAP method can be obtained. The details of the research results can be seen as follows:

Table 5. The Average Competency of Teachers in Writing Inspirational Stories using the ATAP Method

\begin{tabular}{|l|c|c|c|c|}
\hline \multicolumn{5}{|c|}{ Score (\%) } \\
\hline Method & A (Awalan) & T (Tantangan) & A (Aksi) & P (Pelajaran) \\
\hline Average & $48,39 \%$ & $83,87 \%$ & $100 \%$ & $93,55 \%$ \\
\hline
\end{tabular}

Based on the table above, it can be seen that the teacher's average competence in writing the awalan part is $48.39 \%$. This result means that in describing the awalan the teacher finds it difficult. Teachers are competent in describing characters, characterizations, and settings. However, the difficulty in describing the purpose / life expectancy. The teacher's not optimal ability in writing the prefix part will affect the teacher's ability to describe the following sections. This of course does not support learning the factual text genre which is the basis for the implementation of Indonesian language learning, namely learning the factual text genre which uses text as one of the main foundations in carrying out learning [8]

The average competence of teachers in describing challenges was $83.87 \%$. It is easier for teachers to describe challenges than in writing goals. Teachers are competent in describing tantangan, the origin of obstacles (character characteristics, community attitudes, geographic conditions), and telling the flow of problems coherently (introduction to conflict, conflict, climax, and anti-climax). The teacher's ability to tell coherently is also part of higher-order thinking skills, namely a person's ability to solve various problems that are needed through a more careful and complex way of thinking [9]

The average competence of the teacher in describing the aksi was high, namely $100 \%$. All teachers are able to write down actions in solving a challenge. The teacher is competent in describing the character preparation strategies, the steps taken by the characters, and the fun parts or responses of other characters.

The average competence of the teacher in describing the pelajaran was $93.55 \%$. Teachers are competent in 
describing pelajaran that have been obtained from actions, both implied and explicit, providing value and inspiration to readers. From this data, it means that only $6.45 \%$ of teachers do not describe the lesson.

From the results of this research, the ATAP method (awalan, tantangan, aksi, dan tantangan) can be an innovative theory about the method of writing inspirational stories. The results of this study indicate that the ATAP method (awalan, tantangan, aksi, dan tantangan) can develop competency in writing inspirational stories for teachers. Teachers can apply the ATAP method in classroom teaching for writing skills so that students can improve their writing competence because this theory is proven to be easier to apply. Thus, the teacher willit is easier to take appropriate action to seek remedies student learning outcomes. This is as stated by [10] that finds benefits and barriers are essential to tailoring learning accordingly to the needs of students.

\section{CONCLUSION}

Based on data analysis and discussion, the following conclusions can be drawn: The teacher's competence in describing the awalan part falls under the lack of criteria. The results of data analysis showed that the competency to describe the awalan part was 15 $(48.39 \%)$ teachers. Teacher competence in describing the part of the tantangan falls into high criteria. The results of data analysis showed that there were 26 $(83.87 \%)$ teachers in describing the tantangan. Teacher competence in describing part of the action falls into high criteria. The results of the data analysis showed that the competence to describe the part of the aksi was as many as $31(100 \%)$ teachers. Teacher competence in describing parts of the pelajaran falls into high criteria. The results of the data analysis showed that the competency in describing the part of the pelajaran was $29(93.55 \%)$ teachers.

The ATAP method can develop teacher competence in writing inspirational stories because the results of the analysis show that three parts (awalan, tantangan, aksi, dan tantangan) fall into high criteria. Although the prefix part still falls short of the criteria. The ATAP method has proven to be very effective as a method of writing inspirational stories. This method can be a theory of innovation in writing inspirational stories that can be implemented for students to improve their writing skills. Based on the results of this study, there is a need for research related to the ATAP method because this method is not widely used as a written method.

\section{REFERENCES}

[1] E. Kosasih, E., \& Kurniawan, Jenis-jenis Teks Fungsi, Struktur, dan Kaidah Kebahasaan Mata Pelajaran Bahasa Indonesia SMP/MTs. Bandung. Bandung: Yrama Widya, 2018.

[2] E. Sutrisno, Manajemen Sumber Daya Manusia, Jakarta: Kencana Prenada Media Group. 2010. Prosedur Penelitian Suatu Pendekatan Praktik. Jakarta: Rineka Cipta, 2010.

[3] M. Hewi, L., \& Shaleh, "Refleksi Hasil PISA (The Programme For International Student Assesment): Upaya Perbaikan Bertumpu Pada Pendidikan Anak Usia Dini.," J. Golden Age, vol. 4, no. 01, pp. 30-41, 2020.

[4] D. P. N. R. Indonesia, "Peraturan Pemerintah Republik Indonesia nomor 19 tahun 2005 tentang standar nasional pendidikan," 2005.

[5] N. F. Nikmah, N. F., \& Maghfiroh, "Pemnafaatan Video Kisah Inspiratif sebagai Inovasi Pembelajan PPKn guna Meningkatkan Kesadaran Bela Negara pada Siswa," Semin. Nas. Teknol. Pembelajaran dan Pendidik. Dasar, pp. 409-416, 2017.

[6] N. Afnita, A., \& Iryana, "Peningkatan Keterampilan Menulis Teks Cerita Inspiratif melalui Model Discovery Learning Siswa Kelas IX SMP Negeri 1 Kota Sawahlunto. Indonesia," Semin. Bhs. dan Sastra, vol. 2, no. 1, pp. 19-23, 2020.

[7] F. P. Simanjuntak, "Pengaruh Menonton Film Terhadap Kemampuan Menulis Cerita Inspiratif oleh SiswaKelas IX SMP Negeri 40 Medan.," J. Lang. Lit. Teach., vol. 1, no. 2, pp. 107-116, 2019.

[8] Safi'i, I., Tarmini, W., \& Ilyas,H.P. "Learning a Factual Text Genre: An Analysis of the Secondary High School Teachers' Abilities in Developing Learning Devices.," J. Pendidik. Progresif, vol. 10, no. 2, pp. 222-232, 2020.

[9] Safi'i, I., Witdianti, Y., Tarmini, W., \& Yanti,P.G. "Hots Evaluation Instruments in Indonesian Language Textbooks," Retorika J. Bahasa, Sastra, dan Pengajarannya, vol. 13, no. 2, pp. 376-386, 2020.

[10] Tarmini, W., Safi'i, I., Witdianti, Y., \& Larassaty, S. "Peningkatan kompetensi profesional guru melalui webinar evaluasi hasil belajar bagi guru-guru MTs Al-Ma'arif 1 Aimas," Transform. J. Pengabdi. Masyarakat, vol. 16, no. 1, pp. 53-62, 2020. 